\title{
DE MAKELAARDIJ.
}

Uвно Streedrà , De Makelaardij. Academisch Proefsclirift. Groningè 1869.

De redàctie van de Economist heeft mij de tissertatie, waarvan de titel azil hêt hoofd vail dit op'stel is geplaatst; toegezonden mét verźoek die ifi de Ecotronhist te willen bespreken. Gadrne vold de ik aan dat verzoêr, tiat alleen on het belang van het orderiwerp, waar b'olk b́miat het pröefšchrift zelf de blijkèn draagt van erristige

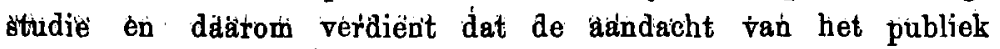
daarop worde gevestigd.

$N a \dot{~ i n ~ e ̀ e n e ~ i t i l e i d i n g ~ o p ~ h e ̀ t ~ b e ̈ l a n g ~ d e r ~ m a l k e l a ̈ a r d i j ~ e n ~ o ̂ p ~ d e ~}$ behoefte ann bèterè régelindy dúarvan gewèzen te hebben, verdeelt de \$. ziji wierk in drie deèlen; werpt $1^{\circ}$ eèn blik op de gèschledenis

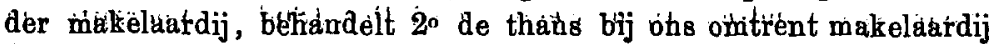

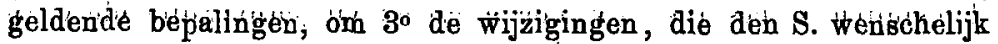
voborkomen, te bésprèlén.

In het eerste hoofdstuk wotdt dé gèschiedenis dét makelaardij behandeit bn wel eerst in $\S 1$ de makelaardij bij de Romeinen. Blijkens den titel der Pandecten, de Proxeneticis, waren de makelaars bij de Romeinen bekend, zij werden niet alleen gebruikt bij het koopen en verkoopen, maar ook tot het opnemen van gelden, zelfs tot het sluiten van een huwelijk.

In $\S 2$ wordt het ontstaan en de ontwikkeling der makelaardij in Duitschland uiteengezet. De S. volgt daarin Laband, Die Lehre von den Mäklern (Zeitschriff für Deutsches Recht XX, p. 2), die teregt het ontstaan van door de overheid aangestelde en beëedigde makelaars afleidt uit twee oorzaken: $1^{\circ}$ de behoefte van den handel aan tusschenpersonen of bemiddelaars, die waarborgen opleveren voor trouw en eerlijkheid en $2^{\circ}$ de behoefte van den handel aan een eenvoudiger bewijsmiddel dan het gewoon maatschappelijk perkeer in de middeleeuwen kende, de acte voor het gerigt. Vandaar dat de handel zelf, waarin in de middeleeuwen een soort van vertrouwen 


\section{5}

whs toegekend, personen benoemde om handelszaken te constateren. Aan die functie is nog de naam Sensal ontleend, waaronder de makelaars in Duitschland bekend zijn, en die met Censualis, eén sỳnoniem van Instrumentarius, in verband staat.

Daarom waren in de verschillende staten ran Duitschland makelaars bekend als door de overheid aangestelde en beëedigde tusschenhandelaars, wier boeken èn acten (Schlusznoten) bewijs leverden der door hen gesloten overeenkomsten. Zoo kent ook het Duitsche hándels-wetboek de makelaars of Sensalen, en regelt huunen toestand en beroegdheid in art. 66 tot en met 84 .

In Fránkrijk ( $(3)$ waren ook reeds vroeg makelaars bekiend en door wettelijkè bepalingen geregeld. De oudsté bekende verordening op dát stuk in Frankrijk is die van Philipus II in 1332, waarbij den makelaars verboden wordt handel te drijvẹn in de warèn waarin zij als makelaars optraden en waarbij tevens wordt verboden: "que nul ne puisse user de courretage sáus le congée du mestre „du riestier ou de son consul dou lieu ou de la justice, si mestre "ni avaiait et jusquess à tánt que deviant le mestre ou la justice il "aurait fait le serment, que faire doivent ou devrout les courretiers."

Dit beginsel is steeds volgehouden tot aan de revolutie. Niemand mogt als tusschenhandeláar optreden zonder aangésteld te zijn. Het getal makelaúrs was bepaald eh hunne charges wèrdèn vétkocht. Na de omwenteling echter en de opheffing dèr gildén, werd ook de tusssehenhahdel geheel vrij verklkard. Spóedig echter bleek het, dat de vrijheid te groot wás. Onwáardige pérsonen tradén als makelatars op, en om dit te keeren wèrd bij dé wett van 28 Veindemiaire An IV de bediening tan agënts de change et

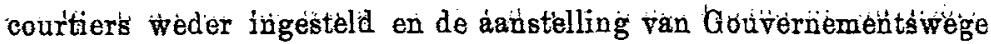
wèter ing gevoetd. De wet vàn' 28 Véntôse an IX régeldé vérder de makelaardij. Deze tóéstand wèrd dơor den Códè dé Cómunérèce bev̈estigd. Ook thans nog wordt eenè aanstelling door den Keízer gevorderd; ook thains nog hebben de makelaars een uitsluiteud regt. Ten aanzien van de bewijkkracht der boeken kwam de Cod'e niet tot een bepáld resultaat. Wel kende hij aan "le boridereau „ou arrêté d'un ageńt de changé ou courtier dûmént signee pàr les „parties," art: 109 Códe de Cöm., volledige bèwijkkrabhit tóe; äán het boek échter werd älleèn bewijskracht toegéekend, indien de handeling in het àlgemèèn bew̌ezen was.

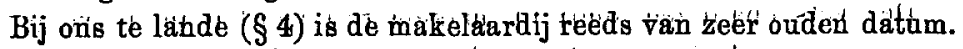

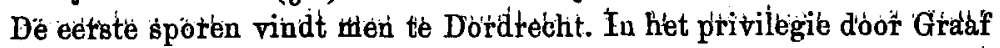
Floris dè $V$ in 1284 äan Dordrècht gegevene, verklaart de Graaf, dat 


\section{6}

hij geen makelaardij binnen Dordrecht zal weggeven of verkoopen „of verlienen" of verhuren „n $\mathrm{n}$ ware dat elc man, die goet man es "ende porter hem daaraan ghenern zal als scepene ende raet met onsen "Bailiu en met onsen rechtere coeren, versieren en overeendraghen."

Diensvolgens raardigden "Bailiu Rechteren scepene en raets"mannen in Dordrecht" den 18 October 1291 een keur uit op het stuk der Makelaardij, en in 1334 gaf Graaf Willem III een handvest, waarbij de makelaardij uitvoerig werd, geregeld en hetwelk het verbod om handel te drijven in waren, waarin zij als makelaars beëedigd waren bevatte.

Te Enkhuizen werd in 1639 eene ordonnantie voor de makelaars uitgevaardigd. In Amsterdam was de ordonnantie van 1533 de eerste poging tot regeling der makelaardij; vroeger schijnt de makelaardij aldaar niet te zijn geregeld. Later werden te Amsterdam herhaaldelijk nieuwe verordeningen op de makelaars gemaakt. De laatste is het Reglement $\operatorname{van} 1797$, hetwelk niettegenstaande de opheffing der gilden bij art. 33 der Staatsregeling van 1798 en de invoering van de Code de Commerce in 1811 door de Amsterdamsche Regering en den Amsterdamschen handel werd gevolgd tot op de invoering van het tegenwoordige Wetboek van Koophandel. De invoering toch van den Code de Commerce had practisch weinig invloed op de makelaardij hier te lande. Men hield zich aan het oude, zoo lang de Code gold. De makelaars werden benoemd, niet door den Koning, maar door het Plaatselijk Bestuur en misten dus eigenlijk eene wettige qualiteit.

Hiermede stapt de S. van de geschiedenis af; Engeland wordt hier gemist, zoo ook Italie, niettegenstaande dit. zoo grooten invloed op de ontwikkeling ran het handelsregt gehad heeft. Mededeelingen omtrent de ontwikkeling der makelaardij ook daar te lande zouden zeer gewenscht geweest zijn.

In het tweede hoofdstuk worden de thans hier te lande omtrent makelaardij bestaande bepalingen uiteengezet. In eene inleiding wordt de vraag gesteld, of de wet betreffende de makelaardij door plaatselijke verordeningen kan worden aangevuld, en bevestigend beantwoord, omdat de makelaardij, hoezeer op zich zelf geene zaak van huishoudelijk belang der gemeente, echter op vele punten de huishoudelijke belangen der gemeente raakt. Tot gelijk resultaat was ik gekomen in mijn Handelsregt $I$. bl. 122.

De wetsbepalingen omtrent makelaardij worden in de volgende rubrieken rerdeeld: $1^{\circ}$. Aanstelling en beëediging der makelaars; $2^{\circ}$. werkzanmheden en loon; $3^{\circ}$. pligten der makelaars; $4^{\circ}$. Bewijs- 


\section{7}

kracht der makelaarshoeken; 5n. aansprakelijkheid, schorsing, vèvallenverklaring. In die verschillende onderdeelen behandelt de $\mathbf{S}$. zeer naauwkeurig de bepalingen der wet omtrent makelaardij in verband met de plaatselijke reglementen. Hij bespreekt daarbij de voornaamste quaestien, waarvan de meesten reeds herhaldelijk in verschillenden zin zijn beantwoord.

Dat ik het met zijne oplossingen niet altijd eens ben, blijkt uit het hoofdstuls "de makelaars" van het Handelsregt, eerste deel bl. 115. Over het algemeen getuigen echter die oplossingen van scherpzinnigheid en groudig onderzoek. Soms echter hecht de S. te veel aan eene voorouderstelde bedoeling des wetgevers, die niet in de woorden der wet is uitgedrukt. Zelfs dan wanueer de redactio der wet in eenen tegen die vooronderstelde bedoeling overgestelden zin is veranderd, blijft de $\mathbf{S}$. aan die bedoeling vasthouden. Zoo verbood b. v. het Wetboek van 1830 den makelaars "handelsverrigtingen te doen"; ons Wetboek verbiedt hun "handel te drijveu" en toch bestrijdt de $S$. met kracht, de mijns inziens juiste meening van de Pinto, dat daardoor alleen eene frequentia actunm, en niet alle op zich zelf staande handelsverrigtingen worden verboden. Zoo stelde het Ontwerp van het Wetboek van Koophandel van 1825 , art. 11 (Wetboek van 1830 art. 52 , thans art. 70 Wetb. van Kooph.) de makelaars verantwoordelijk "voor de laatste onderteekening van wisselbrieven" enz.; het tegenwoordige art. 70 echter stelt hem verantwoordelijk " voor de echtheid van de zich daarop bevindende handteekening van den rerkooper" en toch meent de S., dat de makelaar voor de laatste onderteekening moet instaan, niettegenstaande die niet is de onderteekening des verkoopers, maar het blauco endossement van een der vroegere houders. De verandering der redactie zoude dus geheel doelloos geweest zijn.

Erenmin hecht de $S$. aan de woorden van art. 68 ten aanzien van de bewijskracht, welke daar aan ,de aanteekeningen door den makelaar uit zijn zakboekje in zijn dagboek overgebragt," wordt toegekend en meent, dat het dagboek alleen bewijzen kan, en zulks niettegenstaande een voorstel door eene der sectiën gedaan om in art. 68 in te roegen de woorden ,of onmiddelijk in zijn dagboek aangeschreven of opgenomen" door de Regering als hoogst gevaarlijk niet is aangenomen.

De woorden der wet zijn de eerste grondslag tot hare uitlegging, niet minder dan de bewoordingen eener overeenkomst voor de uitlegging van deze, art. $1378 \mathrm{~B}$. W. Ik geloof dat de S. dit beginsel wel ecns te gering acht. 


\section{8}

In het derde hoofdstuk gaat de S. over tot het jus, constitupandum. Hij meent dat de geheel vrije uitoefening der makeliqardij zophler aanstellling of beëediging ẹ zọder tuşschenkomsțt vąn het administratief gezag, het stelsel der toekomst mag genoemd worden.

Hij is dan oolk zeer ingenomen met het Wetsontwerp door den Minister Wintgens in de zitting van 1867 op 1868 bij de Tweęde Kamer ingediend, waarbij alle ambtelijk karakter aan de mạkeląars ontnomen wardt, en aan ieder die wil, de gelegenheid wordt gegẹen om in naam en voor rekening vạn anderen dadẹn van kqophandel te verrigten, welk Ontwerp is opgemaakt overeepkomstig het verlangen van de Amsterdamșche en Rotterdąmsche Kamers vạn Koophandel, die beide zich tegen het beginsel vạn ąanștelling der makelaars hebben verklaard.

Wanneer de handel meent geen behoefte te hebben aan onpartijdige tưsschenhandelaars, - wapt als zoodanig zullen de makelaars ophopden te bestaan, door de afschaffing van het verbod opm eigen handel te drijven; - wanneer de handel meent de malkelaars als ambtenarẹn, als senșales (Censuales, Inștrumentarii) te kunnen missen, dan zal ik mij niet vermeten de noodzakelijkheida vạn zoodanige personen te bew eren. Waạr deskundige handelaars meenen, dat de dubbele behoefte van dẹn handiel, die ạanleiding gegeven heeft tot het aanstellen vap makelaars, veranderd is, dat er geẹne behoefte meer bestaat an onpartijdige tusschenhandelạars, noch aan instrumentarii van den handel, aan mannen, wier ambtelij.k karaktter aan hup̣ne boekten een bijzondere bewijskracht verschạt, dan zal ik nieț trachten aan te toonen dat die behoefțe wel bestaat. Ik kan het echter niet ontveinzen, dat het hoofdargument voor de afschạfing van de ạanstelling en de beëediging ạangevoerd, mij pijnlijk aandoet. Het is de bewering, dat de makelaars een eed afleggen, die zo.o dikwijls verkracht wordt, zoo als de Amsterdamsche Raad zich uitdrukt, een eed, die, volgens anderen, onmogelijk na te komen is. Ilk zie niet in, waarom. Indien toch een makelaar behalve zijne makelaardij, eigen handel wil drijven, dạ staat hem dat volkomen vrij, mits hij slechts zijn ontslag vrage als makelaar. Dạn ịs hij vrij. Hij kan makelen zooveel als hij wil, want het makelen is geen monopolie der makelaars. De tusschenhandel staat ieder vrij. Hij kan bovendien eigen handel drijven, zooveel hij wil, want het verbod van eigen handel is alleen op makelaars, niet op tussschenhandelaars zonder aanstelling, toepasselijk. Wil hij echter makelaar blijven, wil hij de voorregten (z,oo er zijn) blijven genieten, die aan de qualiteit van makelaar zijn rerbonden, dan moet hij zijn eed 
houden en geen eigen handel drijren, dat toch verbiedt hem zijn eed.

Ofschoon ik mij dus met het Ontwerp van den Minister Wintgens als voldoende aan het verlạngẹn van dẹ hạpdel wel zoude kunnen vereenigen, geloof $\mathrm{ik}$ echter dat de bepaling van art. 6, niet meer in dergelijl ontwerp to huis behoọt.

Wanneer toch aan de makelaars hun karakter van onpartijdigdigheid, door afsehaffing van het verbod van eigen handel en hun ambtelijk karakter, door afschaffing der aanstelling en beëediging, ontnomen wordt, verliezen zij $99 k$ de bevoegdheid om buitengewone bewijskracht aan hunne boeken mede te deelen. Hun boek kan dan bewijg opleveren gelijk andere koopmansboeken, niet meer. Het kan geen bewijs opleyeren tusschen derden, maar alloen voor of tegen den koopman.

Thans leveren makelaarsboeken dat bewijs, omdat de makelaars hebben een ambtelijk karakter, zij zijn door de Overheid aangesteld en beëedigd. De makelaars zijn een soort van handelsnotarissen. Dit karakter kan niet toegekend worden aan alle personen die zich met tusschenhandel afgeven, nadat de aanstelling en beëediging zullen zijn afgeschaft. Dan zijn de tusschenhandelaars geheel en al bijzondere personen, die geenerlei meerderen waarborg opleveren dan andere handelaars, personen, wier op zich zelf staand getuigenis in regten geen bewijgs kan opleveren.

Zoo men aan hupne geschriften bijzondere bewijskracht toekent werpt men onze bewijstheporie omver, on stelt den handed bloot aap groote gevaren.

Ieder kqopman togch zal dian tussschenhandel kunnen drijpen, daardoor makelagr wrorden, en als makela bịnd tenissen fusschen andere koopliepden anngegaan kunnen bewijzen.

J. G. Krst. 